\title{
K. Sello Duiker's Thirteen Cents: An Indictment of South Africa's Post-Apartheid Society
}

Dr. Chinyere T. Ojiakor, Asso. Prof. Aloy Nnamdi Obika

\author{
Department of English, Madonna University Nigeria, Okija Campus, Anambra State. \\ Email: tcorjiakor@gmail.com \\ Department of English, Madonna University Nigeria, Okija Campus, Anambra State. \\ Email: aloyobika@yahoo.com
}

\begin{abstract}
Thirteen Cents is set in Cape Town, South Africa following the 1994 democratic election of Nelson Mandela which formally marked the end of apartheid. While Duiker does not comment on government affairs directly, the social and political context of post-apartheid South Africa as it applies to the individual constitutes a major part of the novel. The child narrator witness's crime, violence and misery upon his arrival in Sea Point. Soon enough, the reader realizes that this witnessing initiates further exploration of crucial aspects of postApartheid life in the city - how and why, for example, Cape Town, the inhabitants, and certain neighbourhoods, Sea Point in particular, are poorly considered. This study investigates the complications of freedom. A racial divide once enforced by law has become an economic divide that falls mostly along racial lines. Scholarly interpretations on Duiker abound but some measure of novelty in this work, though, is the way in which Sea Point is mapped in a very detailed manner, providing a clear, physical sense of the city. The study alternates between the realist and surrealist traditions as the protagonist experiences different realms of consciousness in other to stimulate the author's critique of South Africans society. Duiker provides an excruciatingly realistic description of the dislocation and breakdown of communities and families in post-liberation South Africa. However, the apocalyptic ending as perceived through Azure's eyes indicates the possibility for the growth of a more hopeful future.
\end{abstract}

Keywords - Indictment, Sello Duiker, South Africa, Society, Thirteen Cents.

\section{INTRODUCTION}

South African society continues to undergo an array of societal changes, thereby forcing South African authors to adapt the style and themes of their texts in order to incorporate these socio-political changes into their writing. Post-apartheid literature is a genre of literature that has evolved concurrently with post-apartheid South Africa, as this field of literature presents the problems of a more modern South African life. In response to the sociopolitical changes writers have logically shifted their focus from apartheid political issues to a wider dimension of other issues faced by South Africans in the era of democracy. Killam and Kerfoot sum up the characteristics of post-apartheid writing in the Student Encyclopedia of African Literature:

Just as apartheid defined South African writing during its predominance on the political scene, so post-apartheid writing is influenced and defined by the political past experiences after apartheid that led to a more forward-looking perspective. Post-apartheid writers focus both on the past, on the present, and the new challenges and promises of the post-apartheid era (24).

The transition in the South African political landscape has ushered in a period of change in the focus and writings of South African authors, as they now had more freedom with regard to the choice of themes and content of their texts. This point is emphasised by Attwell and Harlow: "Under apartheid, writers were expected to address the great historical issues of the time, whereas now they are free to write in a more personal key" (4). According to Attwell and Harlow, the period of transition challenged writers, but it did not silence them. Instead, these literary critics continue to argue that:

South African literature since 1990 emphasizes the imperative of breaking silences necessitated by long years of struggle, the refashioning of identities caught between stasis and change, and the role of culture - or representation - in limiting or enabling new forms of understanding (3).

South Africa today is a grand experiment in multicultural democracy, where the leadership is black, money largely 
white and the line between empowerment and exploitation ever shifting. The preamble to the 1996 Constitution - perhaps the most significant document to emerge from the post-apartheid period, if not the country's entire history - says, in the words of Rachel Donald that, "South Africa belongs to all who live in it, united in our diversity"(Retrieved Dec. 3). The unity is willed: not quite a facade but not quite a foundation, either. Because of a unique socio-political history, the majority of South Africans are trapped in a culture of violence and intolerance which is manifested in family, social and community violence. The current South African society is characterised by a high level o $\mathrm{f}$ frustration, anomie and normlessness. These phenomena coupled with poverty, unemployment, overcrowding, increasing urbanisation, lack of health, educational and welfare facilities, give rise to what Schurink calls, "the intensifying of a problem already posed by street children in the South African society" (276). K. Sello Duiker has produced works of extraordinary range and diversity. De Vries says, "Duiker is a post-apartheid remix of South Africa. Self-assured, confused. Energetic, searching. Those are also the themes that re-occur in his novels" (23). Described as "a post-apartheid remix of South Africa" by de Vries above, K. Sello Duiker, even in his short stint as a writer, is to date, arguably, the most prolific of the new generation of post-apartheid South African writers. It is regrettable that Duiker died at such a young age and at the time when he was beginning to gain wide recognition as a writer of note who had begun spearheading the new direction that post-apartheid writing would take. His novels demonstrate an extraordinary range of diversity in their form, themes and characters. In analysing Duiker's novels one acquires a better understanding of this author and his purpose in writing these three texts, an understanding of the world that contributed to the creation of his texts as well as his valuable contribution to South African literature generally. Insight into the fictional worlds of these texts allowed for a careful investigation of the prominent societal issues prevalent in Duiker's work - a world riddled with violence, issues of sexuality and psychological distress. Thus, Duiker is an author who has embraced the transition in South Africa and used it to his advantage as a writer, especially with regard to the content and characters portrayed in his texts. The Cape Town of Thirteen Cents is not the world the cities designer architects would have us thinking it is. There's an Azure, the book's main character, on every corner. All of Duiker's novels were written before his death in January 2005, but they are a hotbed of the fires that are burning fiercely now around race, identity, corruption, molestation, marginalization, inequality and the psychological dysfunctionality of characters. According to Mark Heywood:

Today the forces affecting us are centripetal rather than centrifugal; we are attaching ourselves to surfaces rather than something deeper. The growth of evangelical religions seems to suggest many people have given up on the present and will rally around an identity forged in the invented past and impossible future. Much of this anxiety is linked to growing inequalities and different experiences (Retieved Feb. 18).

In his young life, Duiker was a rising star, anointed as a spokesman for his vexed generation. At the tender age of 28 , he has had two novels published and is well into his third. Duiker is regarded as one of the post-apartheid writers who depict the actualities of living in democratic South Africa and presenting the societal evils that accompany democracy. Duiker reiterates this when he discusses the purpose of a writer: "The writer, he says, is writing for the other. He wants to show what he's like and open eyes that have never been seen" (13). Although Duiker was clearly contending with mental illness, his suicide has come to seem a result of external as well as internal pressures

\section{REVIEW OF LITERATURE}

Scholars have interpreted Thirteen Cents as a critique of South African society and, more specifically, of the issue of the helpless in the society. Mamadou Abdou identifies the novel as "an indictment of South African society" (44). Publishers Weekly opines that, "Thirteen Cents is an extraordinary and unsparing account of a coming of age in Cape Town". Every city has an unspoken side. Cape Town, between the picture Postcard Mountain and sea, has its own shadow: a place of dislocation and uncertainty, dependence and desperation, destruction and survival, gangsters, pimps, pedophiles, hunger, hope, and moments of happiness. Living in this shadow is Azure, a thirteen-year-old who makes his living on the streets, a black teenager sought out by white men, beholden to gang leaders but determined to create some measure of independence in this dangerous world. Cape Times opines, "Thirteen Cents goes to the core of what has been a clear subject of avoidance for writers: the astonishing rate at which children are now victims of a (violent) society intent on turning a blind eye to the plight of its weakest members". Zakes Mda's novel Ways of Dying is centred on similar themes, based on the issues prevalent 
in post-apartheid South African society. Like Duiker, Mda also incorporates dreams, fantasy and violence into some of his texts. His character Toloki is also a street dweller dealing with the complexities of functioning as a well-balanced individual. The author constantly refers to violence throughout the text: "All it means is that we engage in an orgy of drinking, raping, and stabbing one another with knives and shooting one another with guns. And we call it a joll" (25). Another post-apartheid author to delve in dysfunctional society is Phaswane Mpe. Welcome to Our Hillbrow addressed to Refentše reads as a reflection on his life as well as on the issues prevalent in the post-apartheid South African society. This novel is similar to Duiker's Thirteen Cents with regard to the particular societal issues explored by the author. Poverty, drug abuse, violence and corruption are the major themes examined in this text and how these impact the various characters in the novel. The society depicted by Mpe is emphasised in the first chapter of the novel:

Five men were found with their ribs ripped off by what appeared to have been a butchers knife. . .Two women were raped and then killed in Quartz Street. . . Three Nigerians who evaded arrest at Jan Smuts Airport were finally arrested in issues affecting the post-apartheid era in South Africa. In both authors' texts the lives of the characters are portrayed as being a continuous struggle for survival. Pretoria Street for drug dealing. . . Street kids, drunk with glue. . . (5).

From this quote one can see the parallels between the content of Duiker's and Mpe's novels, where both authors have shifted their focus from race concerns to the issues affecting the post-apartheid era in South Africa. In both authors' texts the lives of the characters are portrayed as being a continuous struggle for survival.

\section{ANALYSIS}

In Thirteen Cents Duiker presents the world through the eyes of his main character Azure, a teenager facing the dangers of living on the streets of Cape Town. For Azure, every day is a struggle against the social problems prevalent in modern South African society. It was this experience in Cape Town that contributed to the themes portrayed in this novel based in Sea Point. Duiker states:

The people on the streets of Sea Point always had something to say, something to gossip about, even something to warn one against. There were 13-year-old drug pushers, undercover cops, pickpockets, even members of the Moroccan and Russian mafia. There they all were, part of a vibrant and ever-changing Sea Point; some in business, some out, some suffering extortion and others bribing cops ( 9 ).

Here Duiker highlights themes of violence, sexuality, dreams and a search for identity. Azure has to fend for himself against the physical and psychological abuse of the gangsters and drug lords, the powerful characters who dominate this fictional world. Duiker's focus on violence and abuse in the text is reiterated when Azure is physically assaulted by one of the more powerful characters:

He kicks me in the ribs as I'm about to get up. The sun is hot, hot. "Get up," he tells me. I get up, holding my broken ribs. He punches me again with a strong left hook. I stagger and land on my face. He kicks me in the head and stamps on it, grinding me into the tar road. (38-39)

Shaun Viljoen identifies three conventional boundaries of fictional representation which Duiker crosses in Thirteen Cents - "he graphically depicts sex between child and adult, he does so specifically in relation to homosexual acts, and he uses expletives and the language of insult in a sustained manner that goes beyond inflecting the prose with local colour"(xxv). Duiker himself said "I don't go out intentionally to shock. A lot of what I said could have been toned down. But violence is so much a part of our culture that if I had toned it down it wouldn't have been authentic" (xxv). In general, Duiker approaches diverse social issues from an unusual angle, an angle not often taken by other authors. Clive Hanekom remarks this in his article:

For many aspiring South African writers he was a role model - someone who fearlessly tackled unconventional themes and explored new terrain. For an older generation of writers, Zakes Mda and Lewis Nkosi in particular, his work epitomized the best of post-1994 South African black writing (30).

In Thirteen Cents Duiker creates awareness and he alerts the reader to the struggles of living in post-apartheid South Africa, where one of his main focus is on street children. In an article titled "The Streets and the Gods of Truth" Duiker highlights this point:

Among the bustle of people making a living by any means necessary, I noticed another ignored member of street life: the street child. For some reason street children seem to stand out more in Cape Town than elsewhere. . . So I couldn't but notice a number of them on my way to college every morning, sleeping huddled together under threadbare flea-infested blankets, neglected and left to fend for themselves (9). 
It is inferred that Duiker was both concerned and somewhat intrigued with the life of the street child and the struggles faced by these members of society. Duiker's empathy and intrigue is evident in the fact that he became actively involved with the street children - an "ignored member of street life". Duiker recalls his involvement with the street children of Cape Town:

And then one day I followed a small circle of street children into their world. . . Time enough for me to discover, that when you live on the street, the world is often a harsh, cold pavement with greedy pigeons competing for food with you, and a dangerous bully around the corner, ready to bludgeon you (9).

Duiker then goes even further in his description of life on the street for children when he contrasts the lives of these children with those of more privileged children in society. He states: "While the world sleeps and other children lie snugly in their beds, these kids sniff glue, smoke buttons and anything else that would make them forget that childhood is passing them by. They are aggressive as a matter of course, tough and streetwise" (9). It can be inferred that the point of this distinction is to encourage one to see the inequalities still prevalent in post-apartheid South Africa and how the lives of children, depending on their social status, differ drastically.

In an interview with Diane de Beer Duiker says: "I know street children exist in other cities, but with Cape Town, a relatively small city, one is always aware of them" (13). This novel focuses more on the social and emotional problems that affect many individuals living in the period after democracy. This point is emphasised in the following comment:

Through blue eyes which shine strangely against skin so dark that he is "almost a makwerekwere" (a foreigner), Azure slices through to the rotten core of Cape Town's underbelly, exploited by men who have too much money and jism and no shame. In its realistic portrayal of racism, stereotyping and the sexual exploitation of children by adults, Thirteen Cents represents the worst of South African life (18).

Duiker's purpose of creating the novel is first, to highlight the plight of life on the street for children/adolescents and how these children are often at the mercy of the dangers that lurk within this environment, like the bully that he mentions in the quote. It is through the eyes of Azure that the reader experiences the world of living on the streets of Cape Town and he provides the reader with an understanding of the post-apartheid society depicted in the novel. In her article "Read this and see street kids with new eyes" Bronwen Müller describes the impact of the characterization in the novel on the reader:

Thirteen Cents is a muscular read; it requires and demands a response from the reader. The gauntlet thrown down by the author is to see humanity in lives lived on the street. You will never look at a street person in the same way after you have read the book (28).

In the beginning of Thirteen Cents Azure begins the story by providing the reader with a description of his physical features. He says: "I have blue eyes and a dark skin. I'm used to people staring at me, mostly grown-ups. When I was at school, children used to beat me up because I had blue eyes. They hated me for it"(1). From this quote one is able to note that from an early age Azure is seen as being different from others and is deemed and treated as an outcast by others in the society. This brings us to the second focus of life in post-apartheid South Africa: racism. David Callenberger further emphasises this point when he compares Azure to Frieda, the protagonist in Zoë Wicomb's You Can't Get Lost in Cape Town. He argues:

Azure, like Frieda, lives in a world of constant racial indeterminacy because his black skin contrasts with his deep blue eyes; therefore, Azure cannot live as a typical black person because black people only notice his eyes, while white Capetonians only notice his skin. Also like Frieda, he too seems metaphorically lost in Cape Town, existing in a raceless purgatory because his body precludes him from embracing specific racial ties (91).

Azure's constant struggle to find his place in society is compounded by the constant judgement and criticism that he gets from the other members in society. This point is again emphasised when Gerald, the bully in the text, addresses Azure:

No, I mean you have to be more black . . . like more black than all of us. You must watch what you wear. Like those shoes. Things like that give you away. Like if people see you and they don't know you right, the first thing they look at is how you look. Right? "Right." "So now they look at your blue eyes and your shoes and they think blue eyes, veldskoene, he's trying to be white. That's how people think (35).

The effect of this continuous social ridicule on Azure is evident when he states: "I wear my blue eyes with fear because fear is deeper than shame" (19). Thus, these two emotions, namely, fear and shame continuously haunt Azure and are contributing factors to his emotional turmoil. Unbridled violence in post-Apartheid South 
Africa is exemplified in the murder of Azure's parents. Azure does not actually witness the death of his parents; however, he is confronted by the gruesome scene when he discovered the bloodied bodies of the parents: "I lost my parents three years ago. Papa was bad with money and got Mama in trouble. The day they killed them I was away at school. I came back to our shack only to find them in a pool of blood. That was three years ago"(2). The vivid description of the murder scene provides evidence that this is a traumatic event that has a drastic psychological effect on the character. After this experience there is a violent rupture of the order on both the personal and social level as this experience seems to change Azure and his behaviour in society. In his discussion about death, not his parents' death but death in general the past traumatic experiences seem to have numbed his feelings. He has experienced death so often that it has somewhat desensitized him to it. Furthermore, it is as if death is a normal everyday occurrence to him. He states:

I've seen too many kids die and disappear. There's no point in getting too close. Just now he gets an overdose from his stupid drugs. And then what? Now I must walk around crying because this stupid boy who has a home ran away to kill himself with drug (7).

Still on violence, Duiker also depicts it is as an everyday occurrence in the novel, as the characters seem to accept this as common practice. In one incident in the novel Azure again informs the reader of his first-hand experience of witnessing Allen, a pimp in the area, killing someone. He casually states: "He's [Allen] killed someone before and I saw the whole thing happen" (13). This again reiterates that death is a recurring theme in the novel and is something that most of the characters have grown accustomed to - it is almost portrayed as a normal part of their everyday lives.

Furthermore, the reader is also provided with a first-hand account of the various negative elements surrounding the characters in the novel, issues such as drugs, murder and suffering. This point is reiterated in a conversation between Vincent and Azure: "Look, I know he [Gerald] does drugs and everything." "Fuck the drugs. Word is he killed some people. Well, let me say he killed a family. Two kids and the wife and husband"(58). This quote reveals the reality of the everyday struggles and predicaments faced by the characters in the novel. Their lives are marked by violence, trauma and drug issues. One can immediately detect the mood created by the text by reading only these few sentences from the novel. The vulgar language and lexis choice give the stark reality of the conditions in which the characters lived. This is as the researcher has stated earlier, quoting Duiker himself "I don't go out intentionally to shock. A lot of what I said could have been toned down. But violence is so much a part of our culture that if I had toned it down it wouldn't have been authentic" (xxv)."

Moreover, Duiker describes post-apartheid South Africa, more specifically Cape Town, as a dark, destructive place with many negative characteristics. This point is evident in Oscar's conversation with Azure. Here Cape Town is personified as he goes as far as to describe the city as an evil woman. He says: "She's bad, Cape Town. She takes you in, in the beginning, but be careful. She'll destroy you if you're not watching" (116). Thus, he portrays the idea that people are almost captured by the city and once they are captured it is very difficult for them to escape the powerful grip/ influence of the city. Here the city is a destructive force and it is also an instrument of change of most of the characters.

The notion of the city as an instrument of change is evident in many instances throughout Thirteen Cents, as evil is constantly emphasised and in most cases Duiker illustrates how society seems to make people evil. The first reference to evil is at the beginning of the novel when Azure is providing the reader with background details of himself and of his living conditions. He argues that the fruit-sellers are evil and he portrays these characters as continuously trying to spite other characters, like himself. This is evident when he says: "I can smell their evil. I know a few kids who are under their evil spell" (1-2). Thus, Azure is convinced that other characters in society, like the fruit-sellers, are part of society's evil influence.

Azure shows signs of being somewhat obsessed with evil and the negative effect thereof on other characters in the novel. He states:

And some of them are so deep in their evil they can change shape. They can become rats or pigeons. Pigeons are also rats, they just have wings. And once you become a rat they make you do ugly things in sewers in the dark. It's true. It happens. I've seen it (2).

This statement reaffirms the fact that Azure has a negative outlook on society and the people therein. It also emphasises how the negative aspects of society are an inescapable part of the characters' lives as they are continuously influenced by the evil/wrongdoings in society. One such character that is negatively influenced by societal issues is Gerald. He is an angry, aggressive and brutal character, one who no longer shows any sign of emotion, remorse or sympathy. Gerald is one of the powerful characters in the novel - he is almost portrayed 
as the kingpin in the society. Most of his actions are marked by violence and he continuously torments the other characters in the novel in order to reinforce his superiority and position in the society. Azure suffers the brunt of Gerald's violent and oppressive ways as Gerald seems to constantly reinforce his powerful position in society by utilising bully tactics to oppress and frighten the other characters. One such incident where Azure suffers the wrath of Gerald is when he goes to meet with Gerald and is severely assaulted by one of his gang members. Sealy actually apologises after punching Azure and says: "'Sorry, I have to do this," he says, "he's watching"' (38). Therefore it is clear that Gerald is like a puppeteer and his allies are his puppets as he is the influential character controlling the actions of the other characters; they are merely doing what Gerald instructs.

This point is further emphasised when Sealy is assaulting Azure:

I get up, holding my broken ribs. He punches me again with a strong left hook. I stagger and land on my face. He kicks me in the head and stamps on it, grinding me into the road tar. I start screaming and grab his leg. He fucks up my face with his fists. My nose starts bleeding and snot runs (38-9).

Survival of the fittest seems to be the order of the day in the Cape Town street life. Each character has to fend for him/herself as the other characters are so consumed with their own well-being that they fail to take into cognizance the struggles of others. This idea is reinforced in the novel when Vincent advises Azure: "You must look after yourself, bra. Do you understand that? No one's going to help you in Cape Town. You must do everything yourself' (98). With regard to Azure's emotional turmoil, Azure, after seeing the effects of violence for himself when discovering the bodies of his parents, continues to be a victim of violence in the novel. This is evident in all the violent and graphic scenes pertaining to violence that he has witnessed. The severity of the violence he has witnessed is evident when he states:

I've seen a woman being raped by policemen at night near the station. I've seen a white man let a boy of Bafana's age into his car. I've seen a couple drive over a street child and they still kept going. I've seen a woman give birth in Sea Point at the beach and throw it in the sea. . . I have seen enough rubbish to fill the sea (142).

Another theme that interrogates Post-Apartheid South Africa is Prostitution. It is apparent that Azure is not naturally attracted to members of the same sex; however, this is a way to ensure a generation of some sort of income. He is merely involved in prostitution because there is a demand for male sexual partners/prostitutes and this makes it easier for Azure to meet some of his basic needs, for example acquiring clothing and food. The fact that he does not enjoy sexual relations with men and just uses this as a method to acquire an income is evident when he describes a sexual scene between him and one of his clients: "He lies on top of me and just grinds his hips against mine. "Why aren't you getting an erection?" he says. I think of Toni Braxton and my dick rises. "That's better," he says and carries on rubbing himself against me" (91). Here Azure actually has to imagine a woman in order to become aroused; thus the only driving force here is the idea of acquiring money to fulfill his physical, not sexual needs. In an article titled "The Price of Pleasure: K. Sello Duiker's Thirteen Cents and the Economics of Homosexuality in South Africa" Timothy Johns reiterates this point. He states:

Thirteen Cents depicts how a banal economic rationale can lie behind forms of sexual experience; which is to say, market forces can have more to do with the determination of sexual orientation than free choice or 'authentic' cultural practice, especially for the most vulnerable. In fact, as the novel indicates, in contemporary South Africa pleasure can only be had at a price: Azure, the hero, a desperate thirteen-year-old street urchin living without any kind of state support or safety net, offers sexual favours to other (usually White and wealthy) men in order to survive (250).

Hence it is out of pure desperation that Azure resorts to prostitution, as if he did not partake in this practice he would have no economic income whatsoever. Azure's clientele base is made up of amphigenic inverts as most of them are married men. Amphigenic inverts can be equated to the modern term of bisexual, as they are interested in partners of the same sex, but are also equally interested in partners from the opposite sex. As already mentioned, all of Azure's clients are men and most of them are, in fact married to women. This is apparent in the statement: "It worries me that I have never done it with a woman and that I've only been doing it with men even though I don't like them" (147).

Another point worth mentioning is how Azure portrays himself as being "captured" by madness. On few occasions in the novel he mentions that he is mad. Firstly, he states: "The madness is inside me" (105) and in another instance he actually comments that other people can see that he is mad: "I suck my teeth and he sees the madness in my eyes" (105). Here, he is commenting that a 
passer-by walking his dog can see his madness; hence Azure sees his madness as being so blatant that others in society can easily detect this. His torment is further emphasised when he personifies the sun, the insects and the birds. He seems convinced that the sun, the insects and the birds can also sense his madness: "I get to the rocks and the sun seems to smile. I can hear insects, birds whispering. He is mad, they say. He is mad. I keep going"(106). Azure's internal conflict is also reiterated by the fact that he almost battles to distinguish between his dreams and reality towards the end of the novel. Furthermore, Azure's behaviour, especially at the end of the novel, can be said to be border-lining psychotic as he has been scarred by trauma, but he is also showing signs of drug-induced psychosis. In a chapter on "Psychosis" Jessica Gören includes a table titled "Signs and Symptoms Associated with Drug-Induced Psychosis" which list the symptoms of this condition as:

Hallucinations (visual, tactile, auditory), paranoia, delusions, anxiety, agitation, grandiosity, disorganized speech and/or behaviour, feelings that events have special meaning related to self and thought blocking/insertion/broadcasting (348).

A symptom that Azure displays towards the end of the novel is hallucinations. This is evident when Azure says: "Later in the night I get so drowsy and tired that sleep drugs me. I start seeing things. I see Gerald burning in the fire and rub my eyes but there is nothing there" (159). This again illustrates that Azure has almost lost touch with reality as there is a blurred distinction between what he thinks he sees and what is actually there. Other symptoms of drug-induced psychosis that Azure also displays are anxiety, disorganised behaviour and thought blocking. Duiker's includes dreams in his work. In this way, thoughts, feelings or experiences that have been repressed by his protagonist can become conscious in a less threatening way - in the form of a dream. It is also important to note that the dream content does not only stem from the unconscious, but it can also emphasise reality and other insignificant events that occur. In Azure's last dream in the novel an important point comes to the fore. Throughout the novel Azure seems to battle to find his place within society as he is treated as an outcast by most of the other characters. The death of his parents also seems to aggravate this situation as, since their deaths, he battles to come to terms with his environment and his identity as his blue eyes have made him an outcast in society. Azure's last dream highlights an important point regarding his identity or lack thereof. This is apparent when he is asked who he is by another character in his dream: "“Now tell me who you are!" "I'm not sure," I tell him, "but they call me blue"" (127-8). Azure's response here indicates how he is uncertain about who he really is, also the fact that he says "they call me blue" illustrates how he almost relies on the others in society to reassure him of his identity. This lack of identity must bother Azure as this issue is now even presenting itself in his dreams. Azure's inability to cope with the trauma that he has endured becomes apparent when he decides to journey up Table Mountain. Here it is as if life has just become too much for him and this is his method to escape from life's everyday pressures, it is as if he has gained a new perspective on life, or so he thinks. This is evident when he is starting a fire and mentions: "I work silently. For the first time I work like I know what I'm doing. I don't think too much. I choose wisely"(1078). Even though Azure seems to feel as if it is the first time that he knows what he is doing, it is evident to the reader that this is the point where his ordeals become more prominent. Another point worth mentioning is how this experience seems to also empower Azure as when he is close to the top of the mountain he remarks: "When I look back down I can see the now-quiet city. It lies weak beneath me. I spit. I'm going to crush you, I tell myself and step up" (105-6). Azure mentions that the city lies weak beneath him, hence the city that destroyed him now lacks the power as he sees it as being beneath him. Instead, the roles seem to be reversed here as he sees himself as the powerful "destroyer". This is like his method of retaliation; the person who is destroyed by society is now the cause of destruction.

Lastly, Duiker concludes the novel with Azure stating:

I breathe in deep and hold it for a while. When I let go, I open my eyes. I have seen the centre of darkness. I have seen the slave-driver of darkness and he is a mad bastard. I know his secrets. I know what he does when we sleep. My mother is dead and my father is dead (164).

The fact that Azure mentions that he has seen the centre of darkness highlights the unhappiness and gloom in his life; this being all the negative aspects that he has endured. Furthermore this quote also reiterates the impact of the societal issues on his psyche and the fact that he mentions "My mother is dead and my father is dead" so many times again emphasises Azure's inability to cope with the trauma of losing his parents at an early age. These factors are responsible for his resultant dysfunctionality.

In conclusion Duiker focuses on controversial topics in the novel which is admirable, as he is willing to reveal life and living in Post-Apartheid South Africa especially the 
dangers faced by children on the street. In examining the themes and characters in the novel one can applaud Duiker for painting a picture of society as he sees it; furthermore, the text makes one feel as if the reader is physically being placed in the world of Azure. In the reader's interaction with this character Duiker forces the reader to experience life in his world and witness the difficulties that he faces on a daily basis. In consideration of this Duiker accomplishes his intention of creating awareness, as this novel sheds light on the hardships faced by the minors in post-apartheid society.

\section{REFERENCES}

[1] Attwell, D. \& Harlow, B. "Introduction: South African Fiction after Apartheid.” Modern Fiction Studies. 46 (1). 1-9. 2000.

[2] Callenberger, David. "You Are Now in Fairyland: The Shifting Nature of Space in the Fiction of Cape Town." Chrestomathy, 5 82-97.

[3] Diana,de Beer."A Fresh New Voice." Pretoria News, 27.August, 13.2001.

[4] Duiker, K. Sello. Thirteen Cents. Cape Town: David Philip Publishers. 2000.

[5] --------- "The Streets and the Gods of Truth." Rhodes Journalism Review. September, 8-9. 2004.

[6] Goren, Jessica. "Psychosis," in Tisdale, J.E \& Miller, D. A (Eds.) Drug-Induced Diseases : Prevention,Detection, and Management. American Society of Health-System Pharmacists. 334-356. 2010.

[7] Hanekom, Clive. "Final Chapter : A Promising Career Cut Short When It Had Barely Begun." Sowetan, 28 January. 30. 2005.

[8] Issacson, M. "The Bruised Prose of Suffering on the Street." The Sunday Independent. 03 September. 182000.

[9] Johns, Timothy. "The Price of Pleasure : K. Sello Duiker's Thirteen Cents and the Economics of Homosexuality in South Africa," in Mugambi, H \& Allan, T. (Eds.) Masculinities in African Literary and Cultural Texts. Oxford: Ayebia Clarke Publishing. 250-269. 2010.

[10] Killiam, G \& Kerfoot, A. Student Encyclopedia of Africn Literature. Westport: Greenwood Press. 2008.

[11] Mda, Zakes. Ways of Dying. Cape Town: Oxford University Press. 1995.

[12] Mpe, Phaswane. Welcome to Our Hillbrow. Pietermaritzburg: University of Natal Press. 2001.

[13] Mark, Heywood. "Literature and Identity: Who's Afraid of K. Sello Duiker?" Retrieved 18 February 2011.

[14] Muller, Brown. "Read this and See Street Kids with New Eyes." Cape Times, 11August. 8. 2000

[15] Ngom, Mamadou Abdou Babou. "Thirteen Cents by K. Sello Duiker:Exposing Street Child Reality in South Africa”(PDF). Journal of Pan African Studies 6(9):44-58. 2014.

[16] Rachel, Donadio. "Post-Apartheid Fiction." in Times Book Review, Retrieved December 3, 2006.
[17] Schurink, E.\& Tiba, M. "Street Children as a World Phenomenon," in Schurink, W. (Ed.) Street Children. Pretoria: Human Sciences Research Council. 10.1993.

[18] Shaun, Viljoen. “Introduction,"in K. Sello, Duiker's Thirteen Cents. Athens: Ohio University Press. 2013. 